\title{
Investigating success factors influencing in e-CRM adoption: Evidence from banking industry
}

\author{
Fariz Taherikia ${ }^{\mathrm{a}}$ and Fatemeh Rezaei ${ }^{\mathrm{b} *}$
}

${ }^{a}$ Assist. Prof. \& Faculty Member, Department of Commercial Management, Firoozkooh Branch, Islamic Azad University, Firoozkooh, Iran ${ }^{b}$ M.Sc. Student, Department of Commercial Management, Firoozkooh Branch, Islamic Azad University, Firoozkooh, Iran

CH RO N I C L E

Article history:

Received September 18, 2014

Accepted 9 December 2014

Available online

December 102014

$e-C R M$

Banking industry

Customer loyalty

Technology adoption

\section{Introduction}

During the past few years, there has been tremendous changes in banking industry through adoption of different services such as electronic banking, automated tellers, point of sales, etc. (Ding \& Straub, 2008; Kumar, 2010; Delone \& Mclean, 2004). Mobile banking has been considered as one of the most value-added technology services. The penetration rate of this technology is undefined in the world, specifically in developing countries, Koo and Wati (2010) investigated the role of trust as a mediating variable in mobile banking environment by performing an empirical study in Indonesia. They reported that the trust could mediate the effects of information quality to perceived usefulness and end-user satisfaction. In addition, the relationships of system quality and perceived usefulness and system quality and end-user satisfaction were somehow mediated by trust. Moreover, trust also represented a direct impact on both end-user satisfaction and perceived usefulness. Finally, their result gave support of the positive relationship between perceived usefulness and end-user satisfaction.

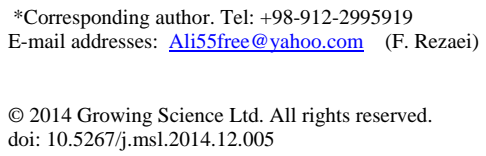


According to Grabner-Kraeuter et al. (2007) and Butz Jr and Goodstein (1997), for more than two decades, customer relationship management (CRM) has become a buzzword among business practitioners and consultants. Many organizations have invested huge amounts of money to implement CRM strategies, techniques and infrastructure to absorb and retain profitable customers in today's increasingly competitive markets. Nevertheless, the existing academic literature and the practical applications of CRM may not provide definite help on how to evaluate the profitability of CRM projects. What is also missing is a comprehensive measurement system that allows a holistic assessment of the ongoing contribution of CRM initiatives to the financial performance of the business firm.

Grabner-Kraeuter et al. (2007) developed a framework for a systematic cost-benefit-assessment and for ongoing performance monitoring of CRM initiatives and proposed an integrated model to determine and measure the effectiveness and efficiency of CRM projects. According to Chen and Popovich (2003) CRM is a combination of people, processes and technology, which looks for understanding a firm's customers. It is a comprehensive technique to manage relationships by concentrating on customer retention and relationship development. CRM has evolved from advances in information technology and organizational changes in customer-centric processes. Many firms that successfully implement CRM may reap the rewards in customer loyalty and long run profitability but successful implementation is elusive to several firms, mostly because they do not understand that CRM needs company-wide, cross-functional, customer-focused business process re-engineering. Although a big portion of CRM is technology, viewing CRM as a technology-only solution may end up having undesirable outcomes. Managing a successful CRM implementation needs an integrated and balanced technique to technology, process, and people.

Kuo et al. (2009) tried to build an instrument to evaluate service quality of mobile value-added services and have a better understanding of the relationships among service quality, perceived value, customer satisfaction, and post-purchase intention. Kaul (2007) evaluated the Retail Service Quality Scale (RSQS) developed in the U.S. and considered valid across a variety of formats and cultural contexts. They argued for further research and extensive scale adaptation before scales developed in other countries such as the RSQS are applied in the Indian context. Zeithaml et al. (1996) offered a conceptual framework of the effect of service quality on particular behaviors that signal whether customers remain with or defect from a firm. They provided strong evidence of their being influenced by service quality. Their findings also disclosed differences in the nature of the quality-intentions link across various dimensions of behavioral intentions.

Wang et al. (1991) developed an integrative framework for customer value and CRM performance based on the identification of the key dimensions of customer value. They explored the decomposed impacts of customer value on CRM performance in terms of relationship quality and customer behaviors. Zineldin (2006) examinee and gave insight about triangle relationship between quality, customer relationship management (CRM) and customer loyalty (CL) which might lead to companies' competitiveness (CC). In their survey, changing in quality over time within different segments or related to specific products or categories of products/services could be applied as an indicator the level of loyalty. Lin and Sun (2009) investigated different factors influencing satisfaction and loyalty in online shopping. They reported that, first, customer e-satisfaction would positively influence customer e-loyalty directly; second, technology acceptance factors could positively impact on customer esatisfaction and e-loyalty directly; third, website service quality could positively impact on customer e-satisfaction and e-loyalty directly; and fourth, specific holdup cost may positively impact on customer e-loyalty directly, but may not positively impact on customer e-satisfaction directly.

\section{The proposed study}

This paper aims to examine the effects of technology adoption and quality of websites on customer satisfaction as well as customer loyalty in banking industry. In addition, the study investigates the effect of electronic customer satisfaction on customer loyalty and the effect of electronic customer satisfaction on customer loyalty on e-CRM (Zaynab, 2007). The study is accomplished among customers of bank 
Sepah in city of Qom, Iran. The study has been accomplished among 94 middle as well as top-level managers who work for different branches on this bank. Fig. 1 demonstrates personal characteristics of the participants.

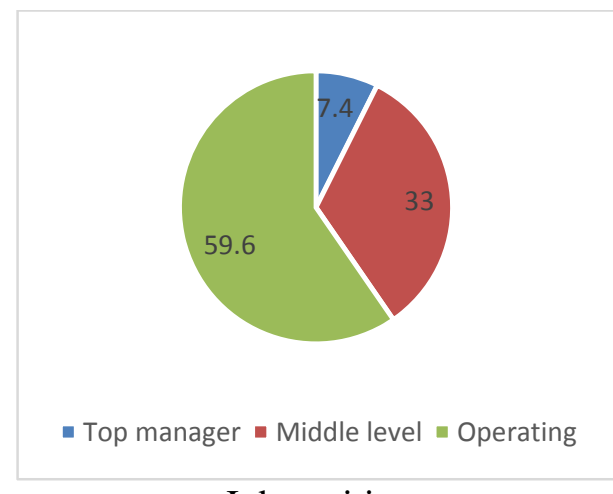

Job position

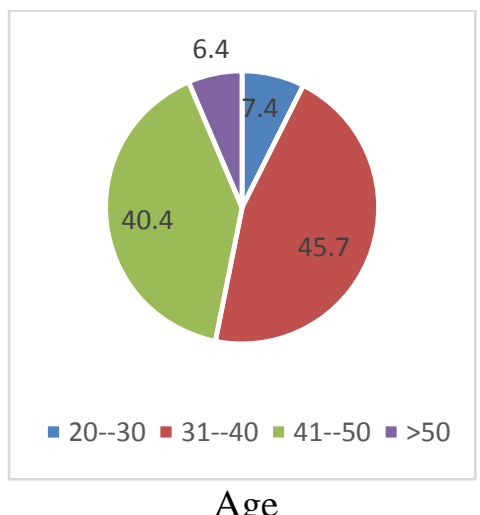

Age

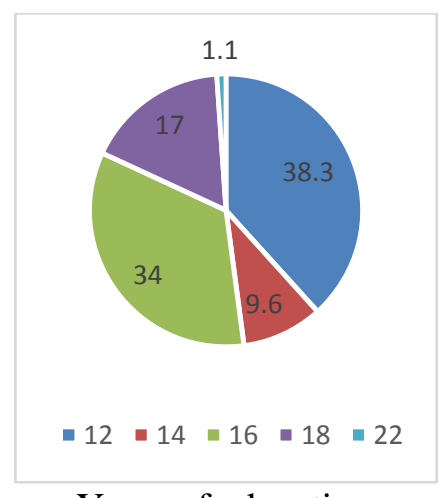

Years of education

Fig. 1. Personal characteristics of the participants

As we can observe from the results of Fig. 1, most participants had good educational background and they were mostly middle aged. The study uses structural equation modeling to verify the hypotheses of the survey and in our survey, all statistical observations were within acceptable levels, which confirm the overall survey. Table 1 demonstrates the results of our findings.

Table 1

The summary of statistical test

\begin{tabular}{|c|c|c|c|c|c|c|c|c|c|c|c|}
\hline \multirow{2}{*}{$\begin{array}{c}\text { Latent } \\
\text { variable }\end{array}$} & \multirow{2}{*}{ Manifest variables } & \multicolumn{5}{|c|}{ Cross-loadings } & \multicolumn{2}{|c|}{ loadings } & \multirow[t]{2}{*}{ AVE } & \multicolumn{2}{|c|}{$\begin{array}{l}\text { Composite } \\
\text { reliability }\end{array}$} \\
\hline & & ADO & QU & SAT & LOY & ECRMP & loadings & CR & & alpha & (PCA) \\
\hline \multirow{6}{*}{$\begin{array}{c}\text { Technology } \\
\text { Acceptance } \\
\text { Model } \\
\text { (ADO) }\end{array}$} & ADO1 & 0.678 & 0.324 & 0.099 & 0.318 & 0.098 & 0.678 & 11.231 & \multirow{6}{*}{0.518} & \multirow{6}{*}{0.815} & \multirow{6}{*}{0.867} \\
\hline & ADO2 & 0.740 & 0.283 & 0.328 & 0.408 & 0.258 & 0.740 & 13.045 & & & \\
\hline & ADO3 & 0.692 & 0.213 & 0.370 & 0.325 & 0.262 & 0.692 & 9.543 & & & \\
\hline & ADO4 & 0.700 & 0.309 & 0.388 & 0.354 & 0.197 & 0.700 & 9.148 & & & \\
\hline & ADO5 & 0.723 & 0.335 & 0.213 & 0.417 & 0.196 & 0.723 & 12.291 & & & \\
\hline & ADO6 & 0.781 & 0.308 & 0.418 & 0.356 & 0.254 & 0.781 & 14.347 & & & \\
\hline \multirow{6}{*}{$\begin{array}{c}\text { Service } \\
\text { Quality } \\
\text { (QU) }\end{array}$} & QU1 & 0.256 & 0.677 & 0.207 & 0.438 & 0.256 & 0.677 & 8.463 & \multirow{6}{*}{0.520} & \multirow{6}{*}{0.815} & \multirow{6}{*}{0.867} \\
\hline & QU2 & 0.331 & 0.629 & 0.231 & 0.292 & 0.212 & 0.629 & 7.564 & & & \\
\hline & QU3 & 0.265 & 0.686 & 0.213 & 0.308 & 0.115 & 0.686 & 8.959 & & & \\
\hline & QU4 & 0.322 & 0.774 & 0.436 & 0.404 & 0.325 & 0.774 & 15.948 & & & \\
\hline & QU5 & 0.301 & 0.758 & 0.329 & 0.403 & 0.448 & 0.758 & 15.040 & & & \\
\hline & QU6 & 0.298 & 0.787 & 0.456 & 0.394 & 0.397 & 0.787 & 13.350 & & & \\
\hline \multirow{3}{*}{$\begin{array}{c}\text { Customer } \\
\text { satisfaction } \\
\text { (SAT) }\end{array}$} & SAT1 & 0.427 & 0.349 & 0.847 & 0.513 & 0.532 & 0.847 & 22.867 & \multirow{3}{*}{0.715} & \multirow{3}{*}{0.801} & \multirow{3}{*}{0.883} \\
\hline & SAT2 & 0.409 & 0.401 & 0.862 & 0.514 & 0.504 & 0.862 & 24.655 & & & \\
\hline & SAT3 & 0.287 & 0.404 & 0.828 & 0.520 & 0.499 & 0.828 & 13.998 & & & \\
\hline \multirow{3}{*}{$\begin{array}{l}\text { Customer } \\
\text { loyalty } \\
\text { (LOY) }\end{array}$} & LOY1 & 0.473 & 0.352 & 0.507 & 0.855 & 0.545 & 0.855 & 21.165 & \multirow{3}{*}{0.757} & \multirow{3}{*}{0.839} & \multirow{3}{*}{0.903} \\
\hline & LOY2 & 0.468 & 0.477 & 0.575 & 0.868 & 0.612 & 0.868 & 31.264 & & & \\
\hline & LOY3 & 0.380 & 0.528 & 0.507 & 0.887 & 0.538 & 0.887 & 33.943 & & & \\
\hline CRM & CRMP1 & 0.297 & 0.398 & 0.463 & 0.525 & 0.822 & 0.822 & 15.906 & \multirow{3}{*}{0.673} & \multirow{3}{*}{0.756} & \multirow{3}{*}{0.861} \\
\hline \multirow{2}{*}{$\begin{array}{c}\text { Performance } \\
\text { (ECRMP) }\end{array}$} & CRMP2 & 0.240 & 0.402 & 0.539 & 0.587 & 0.863 & 0.863 & 26.527 & & & \\
\hline & CRMP3 & 0.207 & 0.228 & 0.488 & 0.484 & 0.775 & 0.775 & 12.830 & & & \\
\hline
\end{tabular}

\section{Results, discussion and conclusion}

According to the results of Table 1, all AVE values are greater than 0.50 , they mostly maintain desirable Cronbach and PCA values. Table 2 and Fig. 2 show the summary of the effects of various variables on each other. As we can observe from the results, technology acceptance (TAM) influence 
on electronic satisfaction (ESAT) and electronic loyalty (ELOY), positively. In addition, electronic service quality (ESQ) influences positively on ESAT and ELOY. Finally, ESAT and ELOY influence positively on e-CRM.

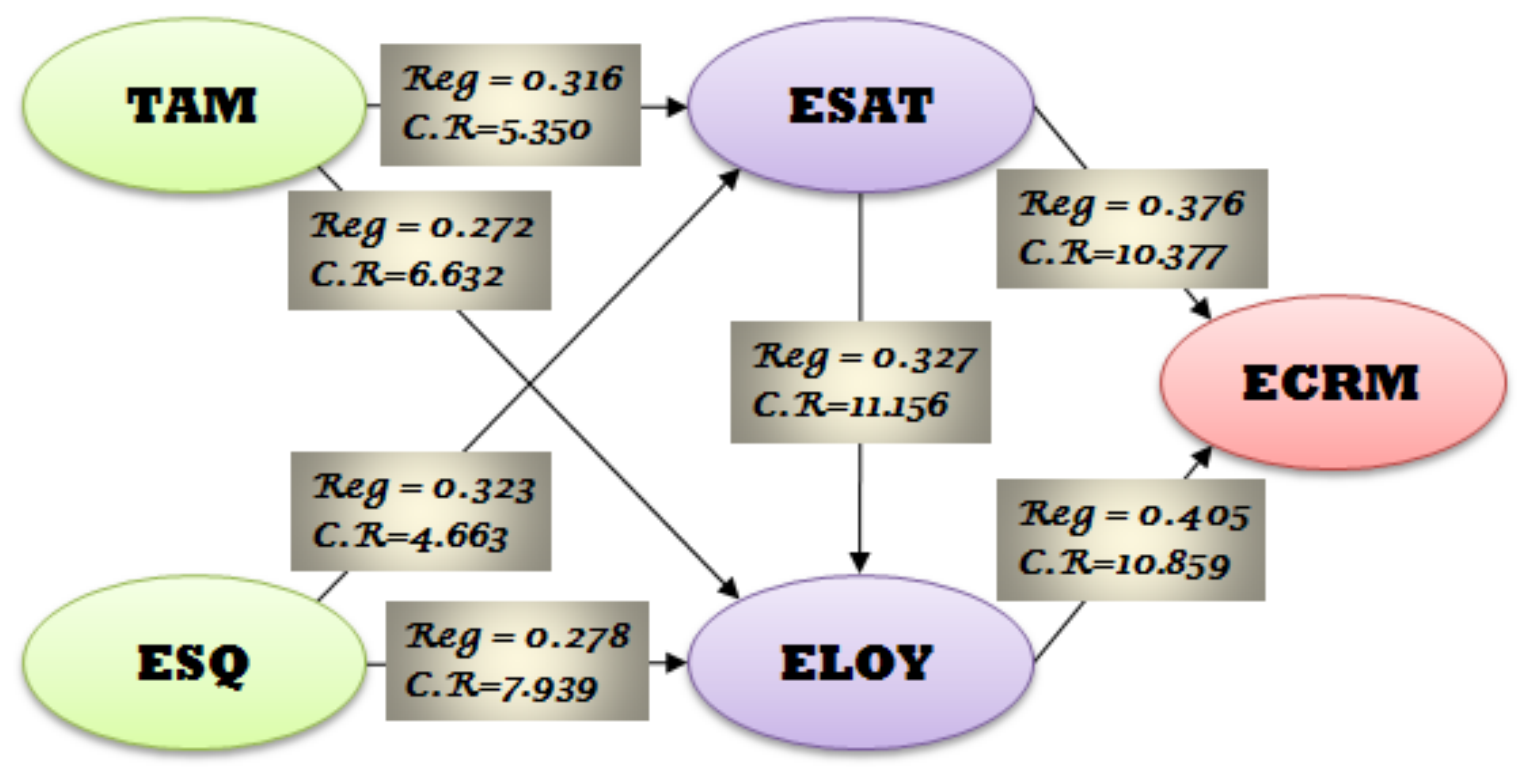

\section{Goodness of fit index: Outer model $=0.998$, Inner model $=0.890$}

Fig. 2. The results of exogenous and endogenous variables

The results of Table 2 also show that all t-student values are statistically significant. In addition, technology adoption as well as quality of services represent $28.7 \%$ of the changes on customer satisfaction. In addition, technology acceptance, service quality and customer satisfaction represent approximately $48.2 \%$ of the changes on customer loyalty and finally, customer satisfaction and customer loyalty represent $49.1 \%$ of the changes on CRM performance.

Table 2

The results of testing various factors

\begin{tabular}{|c|c|c|c|c|c|c|c|c|c|}
\hline Exogenous & Endogenous & Value & $\begin{array}{l}\text { Standard } \\
\text { error }\end{array}$ & $\mathrm{T}$ & Q2 & VIP & $\mathrm{R}^{2}$ & $\mathrm{~F}$ & $\begin{array}{c}\text { Variable's } \\
\mathrm{R}^{2}\end{array}$ \\
\hline Technology & \multirow{3}{*}{$\begin{array}{c}\text { Customer } \\
\text { satisfaction }\end{array}$} & & & & \multirow{3}{*}{0.205} & & \multirow{3}{*}{0.287} & \multirow{3}{*}{3.384} & \\
\hline $\begin{array}{c}\text { Acceptance } \\
\text { Model }\end{array}$ & & 0.316 & 0.059 & 5.35 & & 0.988 & & & 0.14 \\
\hline $\begin{array}{l}\text { Service } \\
\text { Quality }\end{array}$ & & 0.323 & 0.069 & 4.663 & & 1.012 & & & 0.147 \\
\hline Technology & \multirow{4}{*}{$\begin{array}{l}\text { Customer } \\
\text { loyalty }\end{array}$} & & & & \multirow{4}{*}{0.365} & & \multirow{4}{*}{0.482} & \multirow{4}{*}{8.269} & \\
\hline $\begin{array}{c}\text { Acceptance } \\
\text { Model }\end{array}$ & & 0.272 & 0.041 & 6.632 & & 0.927 & & & 0.138 \\
\hline $\begin{array}{l}\text { Service } \\
\text { Quality }\end{array}$ & & 0.278 & 0.035 & 7.939 & & 0.948 & & & 0.144 \\
\hline $\begin{array}{c}\text { Customer } \\
\text { satisfaction }\end{array}$ & & 0.327 & 0.029 & 11.156 & & 1.114 & & & 0.199 \\
\hline $\begin{array}{c}\text { Customer } \\
\text { satisfaction }\end{array}$ & CRM & 0.376 & 0.036 & 10.377 & \multirow{2}{*}{0.33} & 0.963 & \multirow{2}{*}{0.491} & \multirow{2}{*}{5.974} & 0.228 \\
\hline $\begin{array}{c}\text { Customer } \\
\text { loyalty }\end{array}$ & Performance & 0.405 & 0.037 & 10.859 & & 1.035 & & & 0.263 \\
\hline
\end{tabular}

The results of this study are consistent with other findings (DeLone \& McLean, 1992; Kotler et al., 2005; Chang et al., 2005; Akbar et al., 2010). Hu et al. (2009), for instance, reported that delivering high quality service and creating superior customer value can result in achieve high customer 
satisfaction, thus effecting the firm's corporate image, and ultimately leading to consumer retention. Akbar et al. (2010) investigated the relationships between hotel service quality failure, customer perceived value, revitalization of service quality, customer satisfaction and loyalty in the hotel industry in Penang, Malaysia. They reported that hotel revitalization of service quality had positive impacts on customer loyalty, while perceived value and customer satisfaction were two important variables that mediated the relationships between hotel service quality and customer loyalty. They also found that hotel service quality had no profound and direct effects, but indirect positive impacts on customer satisfaction.

\section{Acknowledgement}

The authors would like to thank the anonymous referees for constructive comments on earlier version of this paper.

\section{References}

Akbar, S., Som, A. P. M., Wadood, F., \& Alzaidiyeen, N. J. (2010). Revitalization of service quality to gain customer satisfaction and loyalty. International Journal of Business and Management, 5(6), P113.

Butz Jr, H. E., \& Goodstein, L. D. (1997). Measuring customer value: Gaining the strategic advantage. Organizational dynamics, 24(3), 63-77.

Chang, T. M., Liao, L. L., \& Hsiao, W. F. (2005, March). An empirical study on the e-CRM performance influence model for service sectors in Taiwan. In e-Technology, e-Commerce and eService, 2005. EEE'05. Proceedings. The 2005 IEEE International Conference on (pp. 240-245). IEEE.

Chen, I. J., \& Popovich, K. (2003). Understanding customer relationship management (CRM): People, process and technology. Business process management journal, 9(5), 672-688.

DeLone, W. H., \& McLean, E. R. (1992). Information systems success: the quest for the dependent variable. Information systems research, 3(1), 60-95.

Delone, W. H., \& Mclean, E. R. (2004). Measuring e-commerce success: Applying the DeLone \& McLean information systems success model. International Journal of Electronic Commerce, 9(1), 31-47.

Ding, Y., \& Straub, D. (2008). Quality of IS in services: Theory and validation of constructs for service, information, and system. ICIS 2008 Proceedings, 101.

Grabner-Kraeuter, S., Moedritscher, G., Waiguny, M., \& Mussnig, W. (2007, January). Performance monitoring of CRM initiatives. In System Sciences, 2007. HICSS 2007. 40th Annual Hawaii International Conference on (pp. 150a-150a). IEEE.

Hu, H. H., Kandampully, J., \& Juwaheer, T. D. (2009). Relationships and impacts of service quality, perceived value, customer satisfaction, and image: an empirical study. The Service Industries Journal, 29(2), 111-125.

Kaul, S. (2007). Measuring retail service quality: Examining applicability of international research perspectives in India. Journal of Decision Makers, 32(1): 15-26.

Koo, C., \& Wati, Y. (2010). Toward an understanding of the mediating role of "Trust" in mobile banking aervice: An empirical test of Indonesia case. Journal of Universal Computer Science, 16(13), 1801-1824.

Kotler, P. Armstrong, G., Ang, S. H., Leong, S. M., Tan, C. T., \& Tse, D. K. (2005). Principles of marketing: an Asian perspective. Prentice-Hall.

Kuo, Y. F., Wu, C. M., \& Deng, W. J. (2009). The relationships among service quality, perceived value, customer satisfaction, and post-purchase intention in mobile value-added services. Computers in human behavior, 25(4), 887-896.

Kumar, V. (2010). Customer relationship management. John Wiley \& Sons, Ltd. 
Lin, G. T., \& Sun, C. C. (2009). Factors influencing satisfaction and loyalty in online shopping: an integrated model. Online Information Review, 33(3), 458-475.

Wang, Y., Lo, H. P., Chi, R., \& Yang, Y. (2004). An integrated framework for customer value and customer-relationship-management performance: a customer-based perspective from China. Managing Service Quality, 14(2/3), 169-182.

Zaynab, M. (2007). CRM implementation in retail banking in Nigeria-A structured literature review (Doctoral dissertation, Master’s Thesis, Cranfield University, United Kingdom).

Zeithaml, V. A., Berry, L. L., \& Parasuraman, A. (1996). The behavioral consequences of service quality. The Journal of Marketing, 60(2), 31-46.

Zineldin, M. (2006). The royalty of loyalty: CRM, quality and retention. Journal of consumer marketing, 23(7), 430-437. 